\title{
Effect of a specific combination of carvacrol, cinnamaldehyde, and Capsicum oleoresin on the growth performance, carcass quality and gut integrity of broiler chickens
}

\author{
M. H. H. Awaad ${ }^{1}$, M. Elmenawey ${ }^{2}$ and Kawkab A. Ahmed ${ }^{2}$ \\ 1. Poultry Diseases Department, Faculty of Veterinary Medicine, Cairo University, Cairo, Egypt. \\ 2. Animal Production Department, Faculty of Agriculture, Cairo University, Cairo, Egypt. \\ Corresponding author: M. H. H. Awaad, email: awaad3@gmail.com, Tel.: + 02-01006882528 \\ Received: 07-02-2014, Revised: 21-03-2014, Accepted: 27-03-2014, Published online: 04-05-2014
}

doi: 10.14202/vetworld.2014.284-290 How to cite this article: Awaad MHH, Elmenawey M and Ahmed KA (2014) Effect of a specific combination of carvacrol, cinnamaldehyde, and Capsicum oleoresin on the growth performance, carcass quality and gut integrity of broiler chickens, Veterinary World 7(4): 284-290.

\begin{abstract}
Aim: The effect of a specific combination (SC) of carvacrol, cinnamaldehyde, and Capsicum oleoresin was investigated on productive performance and immune response in broiler chickens.

Materials and Methods: Six hundred one-day-old broiler chickens were randomly allocated into two groups for 5 weeks. The $\mathrm{SC}$ was supplemented at $100 \mathrm{ppm}$ of ration (presence or absence).

Results: Treatment of broiler chickens with the SC improved productive performance variables as compared with the blank control birds. It decreased total mortality, increased final body weight, weight gain, production number and decreased final feed conversion ratio $(\mathrm{FCR})(\mathrm{P}<0.05)$. The $\mathrm{SC}$ had a positive effect on carcass quality and enhanced $\mathrm{HI}$ titer against Newcastle disease (ND) virus vaccine, as compared to their untreated control group $(\mathrm{P}<0.05)$. The $\mathrm{SC}$ treated birds had higher values of intestinal diameter than the control ones.

Conclusion: It could be concluded that administration of a specific combination of carvacrol, cinnamaldehyde, and Capsicum oleoresin to broiler chickens improved chicken zootechnical performance response variables, had a potent immunomodulatory effect (potentiated immune response) and improved gut integrity. Eventually, this combination could be used as a replacement to the controversial feed additives (antibiotic growth promoters).
\end{abstract}

Keywords: Capsicum oleoresin, carvacrol, chickens, cinnamaldehyde, gut integrity.

\section{Introduction}

In view of rising concerns on the extensive use of antibiotics in animal production, there is an increasing interest for developing alternative disease control strategy to enhance animal health and to reduce the use of antimicrobials. One promising new possibility to achieve this goal is the use of natural herbal products to enhance feed efficiency, gut health, and innate immunity $[1,2]$. The American Medical Association urged that the use of antimicrobial growth promoters (AGP) in animals should be terminated [3]. Consequently, many governments around the world are banning or severely limiting the use of antibiotics at non-therapeutic levels. All AGP have been banned in the European Union (EU) since the year 2006. Eventually, many other countries will have to follow these measures to export to the EU. Consequently, the poultry industry may be adversely affected by disease challenge and loss of production because of those restrictions [4]. The European ban on AGP use in animal and poultry nutrition has increased infections [5]. Raising poultry without antibiotics resulted in poor performance and enteritis that is economic problem [6]

Copyright: The authors. This article is an open access article licensed under the terms of the Creative Commons Attribution License (http://creativecommons.org/licenses/by/2.0) which permits unrestricted use, distribution and reproduction in any medium, provided the work is properly cited. and animal welfare problem [7]. The challenge will be to fight microbial imbalances in young animals. Feed formulators need efficient alternatives to use as commodities. Consequently, natural alternatives concepts based on natural ingredients for non-AGP and antibacterial action are highly commendable. These alternatives such as probiotics, prebiotics and acidifiers successfully been used by many investigators [8-11]. Herbal products and their oil extracts have been used for natural therapy as pharmaceuticals; however, only in recent years aromatic plants and their extracts were introduced to the animal feeding [12]. Further complications arise because herbal products and their oil extracts feed additives may vary widely with respect to botanical origin, processing, and composition. Most studies investigate blends of various active compounds and report the effects on production performance rather than the physiological impacts [13-15]. Several types of herbal products and their oil extracts have enhanced broiler performance and resulted in growth-promoting effects [13]. The proposed mode of action of herbal products is attributed to their antimicrobial properties $[5,14,16,17]$, antiviral [18], oxidative-resistant activity $[15,19]$, anti-inflammatory $[5,20]$, enhancement of the immune system $[1,2,17]$ and other biological effects $[14,21,22]$ and consequently, improvement in poultry performance. 
Table-1: Composition of the broilers 3-phase diets ( $\mathrm{g} / \mathrm{kg}$ as fed) and their calculated chemical composition.

\begin{tabular}{lcc}
\hline Ingredients & Starter & Finisher \\
\hline Yellow corn & 52.45 & 62.85 \\
Soybean meal 44\% & 33.24 & 22.11 \\
Corn gluten meal 60\% & 7.00 & 6.65 \\
Oil & 3.00 & 4.00 \\
Di-calcium phosphate & 1.80 & 1.80 \\
Lime stone 1.30 & 1.30 & 1.30 \\
DL-Methionine & 0.22 & 0.23 \\
Lysine hydrochloride & 0.29 & 0.36 \\
Sodium chloride & 0.40 & 0.40 \\
Premix & 0.30 & 0.30 \\
Calculated composition & & \\
Crude protein (\%) & 23.00 & 19.00 \\
Metabolizable energy (kcal/kg) & 3000 & 3100
\end{tabular}

* Each 3 gram of premix contained: vitamin A (trans-retinyl acetate), 9,000 IU; vitamin D3 (cholecalciferol), 2,600 IU; vitamin E (dl-a-tocopheryl acetate), $16 \mathrm{mg}$; vitamin B1, $1.6 \mathrm{mg}$; vitamin B2, $6.5 \mathrm{mg}$; vitamin B6, $2.2 \mathrm{mg}$; vitamin B12 (cyanocobalamin), $0.015 \mathrm{mg}$; vitaminK3, 2.5mg; choline (choline chloride), $300 \mathrm{mg}$; nicotinic acid, 30 mg; pantothenic acid (d-calcium pantothenate), $10 \mathrm{mg}$; folic acid, $0.6 \mathrm{mg}$; d-biotin, $0.07 \mathrm{mg}$; manganese $(\mathrm{MnO}), 70 \mathrm{mg}$; zinc (ZnO), $60 \mathrm{mg}$; iron $\left(\mathrm{FeSO}_{4} \mathrm{H}_{2} \mathrm{O}\right), 40 \mathrm{mg}$; copper $\left(\mathrm{CuSO}_{4} 5 \mathrm{H}_{2} \mathrm{O}\right), 7 \mathrm{mg}$; iodine $\left[\mathrm{Ca}\left(\mathrm{IO}_{3}\right)_{2}\right]$, mg; selenium $\left(\mathrm{NaSeO}_{3}\right), 0.3 \mathrm{mg}$.

However, the results of the experiments that have been carried out to evaluate the response of broiler chicks to herbal products and their oil extracts feed additives are inconclusive and presented a scattered picture. Whereas, some investigators have reported no significant improvement in broilers performance due to the herbal products or their oil extracts feed additives $[4,16,23]$.

This paper highlights the activities of usage of a specific combination containing microencapsulated active substances of Carvacrol, Cinnamaldehyde, and Capsicum oleoresin on the growth performance and carcass quality of broiler chickens.

\section{Materials and Methods}

Ethical approval: The experiment was carried out according to the National regulations on animal welfare and approved by Institutional Animal Ethical Committee.

The present study was carried out at the Poultry Research Center, Department of Animal Production, Faculty of Agriculture, Cairo University, Giza, Egypt.

Experimental birds: One-day-old Arbor Acres Plus male broiler chickens were used in this semi-field trial. Chicks were housed in semi-closed house. The chickens were provided with 24 hours light throughout the first three days, then 23 hours light and 1 hour dark until slaughter time (35 days). Chickens were fed a commercial starter diet $(23 \%$ crude protein and 3000 $\mathrm{kcal} \mathrm{ME} / \mathrm{kg}$ diet) during the first two weeks of age, commercial grower diet (22\% crude protein and 3150 $\mathrm{kcal} \mathrm{ME} / \mathrm{kg}$ diet) from 2-4 weeks of age, and then commercial finisher diet (19\% crude protein and 3200 $\mathrm{kcal} \mathrm{ME} / \mathrm{kg}$ diet). Semduramicin was added to the ration at a concentration of $25 \mathrm{ppm}$ as a coccidiostat. No antibiotics were added to the ration. The diets compositions are indicated in Table-1. Feed and water were available ad libitum. All chickens were vaccinated against Newcastle disease vaccine (ND) at $7^{\text {th }}$ and $21^{\text {st }}$ day of age by using live Hitchner B1 and La Sota strain vaccines, respectively. Live infectious bursal disease vaccine (IBD) was administrated at $14^{\text {th }}$ day of age. Drinking water method was used as route of administration of live vaccines. On $10^{\text {th }}$ day of age, 0.5 $\mathrm{ml}$ inactivated Avian Influenza vaccine (H5N1), was injected subcutaneously in the back of neck.

Experimental design: The chickens $(n=600)$ were allotted into two equal groups (1-2) of 300 birds assigned into 10 replicates of 30 each. All pens were located in a same environmentally controlled room. All groups ran contemporaneously. Chickens of group 1 fed on a standard feed ration. Chickens of group 2 fed on a standard feed containing a specific combination (SC) of Carvacrol, Cinnamaldehyde, and Capsicum oleoresin. This product is containing microencapsulated active plant extracts consisting of $5.04 \%$ carvacrol $\left(\mathrm{C}_{10} \mathrm{H}_{14} \mathrm{O}\right.$; from oregano, Origanum spp. $), 2.9 \%$ cinnamaldehyde $\left(\mathrm{C}_{9} \mathrm{H}_{8} \mathrm{O}\right.$, from cinnamon, Cinnamonum spp.) and $2.18 \%$ capsicum oleoresin $\left(\mathrm{C}_{18} \mathrm{H}_{27} \mathrm{NO}_{3}\right.$ from Mexican pepper, Capsicum annuum)]. This combination has been supplemented at $100 \mathrm{~g} /$ ton in the feeds via a premix, on a vegetal carrier.

Productive performance and carcass characteristics: Chicken performance response variables were determined [40]. Weekly individually body weight (wt.) and wt. gain were measured on all birds. Weekly feed consumption $(\mathrm{g} / \mathrm{d} / \mathrm{bird})$, feed conversion ratio (FCR) (g feed/g live body wt. gain), and mortality rate were measured for each replicate. Dead birds were weighed to include their weights in the feed conversion estimation. An index of productivity is the so-called production number [which equals (kilograms of growth per day x (100 - mortality \%) / FCR) x 100] [24] was estimated for each replicate, at the end of the experimental period. Feed consumption was calculated, for each subgroup weekly to investigate the feed conversion ratio (FCR) (g feed/g live body weight). FCR was calculated, for each subgroup, as follows: Feed intake for the subgroup $(\mathrm{kg})$ divided by the total body weight gained for the same subgroup $(\mathrm{kg})$. The total body weights included dead birds during the week. 
Table-2: Effect of the SC on productive performance and mortality of broiler chickens.

\begin{tabular}{lccc}
\hline Productive performance & Control group & SC treated group & P Value \\
\hline Body weight (g) (5 weeks old) & $2064.1 \pm 15.45^{\mathrm{b}}$ & $2175.4 \pm 13.74^{\mathrm{a}}$ & 0.0001 \\
Bodyweight gain (g) (4 to 5 week old) & $614.7 \pm 9.06^{\mathrm{b}}$ & $701.9 \pm 8.16^{\mathrm{a}}$ & 0.0001 \\
Total Feed consumption (g/bird) & $3358.1 \pm 41.37$ & $3404.3 \pm 46.42$ & 0.499 \\
Feed conversion ratio (0-5 weeks old) & $1.627 \pm 0.009^{\mathrm{a}}$ & $1.563 \pm 0.009^{\mathrm{b}}$ & 0.007 \\
Total mortality & $3.67 \pm 0.24^{\mathrm{a}}$ & $3.00 \pm 0.16^{\mathrm{b}}$ & 0.037 \\
Production number & $349.3 \pm 7.34^{\mathrm{b}}$ & $385.7 \pm 5.85^{\mathrm{a}}$ & 0.018 \\
\hline
\end{tabular}

* Means with different superscripts, within row, are significantly different $(P \leq 0.05)$.

Table-3: Effect of the SC on carcass characteristics of broiler chickens

\begin{tabular}{lccc}
\hline Carcass quality & Control group & SC treated group & $P$ Value \\
\hline Dressing \% & $69.07 \pm 0.29^{\mathrm{b}^{*}}$ & $69.96 \pm 0.27^{\mathrm{a}}$ & 0.028 \\
Front part \% & $39.22 \pm 0.33^{\mathrm{b}}$ & $40.22 \pm 0.27^{\mathrm{a}}$ & 0.023 \\
Hind parts \% & $29.99 \pm 0.27$ & $29.75 \pm 0.22$ & 0.503 \\
Breast meat \% & $17.40 \pm 0.31^{\mathrm{b}}$ & $18.84 \pm 0.45^{\mathrm{a}}$ & 0.010 \\
Thigh Drumstick meat\% & $14.25 \pm 0.24$ & $14.52 \pm 0.26$ & 0.445 \\
Carcass meat \% & $31.65 \pm 0.42^{\mathrm{b}}$ & $33.35 \pm 0.65^{\mathrm{a}}$ & 0.033 \\
Abdominal fat \% & $1.45 \pm 0.08^{\mathrm{a}}$ & $1.18 \pm 0.06^{\mathrm{b}}$ & 0.013 \\
Liver \% & $2.61 \pm 0.05$ & $2.54 \pm 0.06$ & 0.345 \\
Heart \% & $0.537 \pm 0.02$ & $0.493 \pm 0.01$ & 0.072 \\
Gizzard \% & $1.43 \pm 0.05^{\mathrm{b}}$ & $1.59 \pm 0.06^{\mathrm{a}}$ & 0.036 \\
Giblets \% & $4.58 \pm 0.08$ & $4.62 \pm 0.08$ & 0.750 \\
\hline
\end{tabular}

* Means with different superscripts, within row, are significantly different $(P \leq 0.05)$.

Daily mortalities were recorded for each subgroup. The European production efficiency factor (EPEF) was estimated at the end of the experimental period, for each subgroup. EPEF was calculated as follows: (Average live body weight (Kg) x Livability (\%) x 100 / (Marketing age (day)xFCR). Carcass characteristics (dressing $\%$, front part $\%$, hind part $\%$ breast meat $\%$, thigh with drumstick meat $\%$, carcass meat $\%$, and giblets (liver + heart + gizzard \%) were measured at 5 weeks of age, on three birds from each replicate.

Relative weights of spleen, thymus and bursa of fabricius (BF): On 35 day of age, determination of the relative spleen, thymus and $\mathrm{BF}$ weights, as a percent of the fasting live body weights, were performed on three birds from each replicate.

Intestinal length and diameter: Intestinal length (duodenum + jejunum + ileum) and diameter (in the middle of ileum) were measured on three birds from each replicate, on the $35^{\text {th }}$ day of age.

Immune status assessment: To investigate the possible effect of the SC on the humoral immunity; an immunoassay was adopted. For this purpose, blood samples were collected from wing vein from 30 randomly selected birds at weekly intervals (1-5 weeks of age) from each group (3 birds/replicate). The serum samples were subjected to haemagglutination inhibition (HI) test for determining antibody titers against ND vaccine employing 8 haemagglutinating (HA) units [25].

Statistical analysis: One-way analysis of variance was used using SAS software general liner models procedure [27]. The main factor was the SC supplementation.
Mean values were assessed with significance set at $\mathrm{P}<0.05$.

\section{Results}

Productive performance and carcass characteristics: Results of feed supplementation with a mixture of SC on productive performance in broilers are presented in Table-2. Addition of SC to the ration of broiler chicks (from 0 to $35 \mathrm{~d}$ old) in a dose of $100 \mathrm{ppm}$ resulted in increase in final body weight $(+111 \mathrm{~g})$, with improve in final feed conversion ratio (-64 units) and total mortality rate $(-0.83 \%)$ and consequently, increase in production number by 37 units, as compared to control group. The data of body weight gain indicated differences between the two groups, except from the $1^{\text {st }}$ to the $2^{\text {nd }}$ and from the $2^{\text {nd }}$ to the $3^{\text {rd }}$ weeks of age. From the first day to the $1^{\text {st }}$ week of age, the control group had higher body weight gain; in contrast, it had lower body weight gain from the $3^{\text {rd }}$ to the $4^{\text {th }}$ and from the $4^{\text {th }}$ to the $5^{\text {th }}$ week of age, as compared to SC treated group. There were no significant differences in daily feed consumption or total feed consumption between the control and the SC treated groups, except during the $2^{\text {nd }}$ week of age (Table-2). Where, the control birds consumed, daily, more amount of feed than the SC treated ones.

The effect of feed supplementation with the SC on carcass characteristics revealed increase in dressing $(+1.8 \%)$, front part $(+1.5 \%)$, breast meat $(+1.44 \%)$, carcass meat $(+1.7 \%)$, gizzard weight $(+0.16 \%)$ as well as decrease in abdominal fat $(-0.27 \%)$, as compared to control birds (Table-3).

No effects were detected on feed supplementation with the SC on relative weights of spleen, thymus, or BF (Table-4). 
Table-4: Effect of the SC on relative weights of lymphoid organs and intestinal morphology in broiler chickens at 5 weeks of age.

\begin{tabular}{lccccc}
\hline Treatment/trait & Spleen $\%$ & Thymus $\%$ & Bursa of fabricius $\%$ & Intestine length $(\mathbf{c m})$ & Intestine diameter $(\mathbf{c m})$ \\
\hline Control & $0.227 \pm 0.01$ & $0.700 \pm 0.03$ & $0.267 \pm 0.02$ & $185.20 \pm 2.84$ & $0.900 \pm 0.04^{\mathrm{b} *}$ \\
The SC & $0.233 \pm 0.01$ & $0.727 \pm 0.05$ & $0.260 \pm 0.02$ & $191.93 \pm 2.24$ & $1.063 \pm 0.03^{\mathrm{a}}$ \\
P Value & 0.649 & 0.644 & 0.767 & 0.094 & 0.002 \\
\hline
\end{tabular}

* Means with different superscripts, within column, are significantly different $(P \leq 0.05)$.

Table-5: Effect of The SC on haemagglutination inhibition (HI) antibody titer against Newcastle disease vaccine in broiler chickens.

\begin{tabular}{lccccc}
\hline Treatment/Age & 1 Week & 2 Weeks & 3 Weeks & 4 Weeks & 5 Weeks \\
\hline Control & $3.38 \pm 0.27$ & $5.48 \pm 0.25$ & $7.32 \pm 0.30^{\mathrm{b} *}$ & $6.25 \pm 0.36^{\mathrm{b}}$ & $5.50 \pm 0.60^{\mathrm{b}}$ \\
The SC & $3.50 \pm 0.18$ & $6.12 \pm 0.39$ & $8.34 \pm 0.35^{\mathrm{a}}$ & $7.72 \pm 0.30^{\mathrm{a}}$ & $7.08 \pm 0.34^{\mathrm{a}}$ \\
P Value & 0.7352 & 0.5442 & 0.0067 & 0.0053 & 0.0092 \\
\hline
\end{tabular}

* Means with different superscripts, within column, are significantly different $(P \leq 0.05)$.

The intestinal diameter increased $(+0.16 \mathrm{~cm})$ in the SC treated group vs. blank controls $(\mathrm{P}<0.05)$. There was increase in the intestinal length of treated group over the untreated control group (191.93 cm vs. 185.80 cm respectively) (Table-4).

Immune status assessment: The results of humoral immune response are presented in Table-5, which indicated increase in the SC treated group over the blank control group in the HI titers against ND vaccine at different examined intervals.

\section{Discussion}

Health of chicken gastrointestinal tract is of great concern due to its impact on economic sustainability, and their customers' concern about food safety and traceability. Comparing treated chickens by a SC with their untreated blank controls revealed a significant improve in broiler productive performance, intestinal diameter, and HI antibody titers against ND vaccine. Many researchers agree with our results and established the improvement in broiler performance, when herbal essential oils were supplemented in broiler diets or water [28-31]. The positive impact on poultry production of the used herbal compound in the present investigation could be attributed to its antioxidant activity [32, 33], enhancing digestibility by stimulating endogenous enzyme activity and facilitating nitrogen absorption [34] and/or its anti-microbial activities as essential oils [16,35 and 36]. A wide range of in-vitro anti-microbial activities of essential oils derived from cinnamon, thyme and oregano has been determined [37]. The antimicrobial functions of these herbs are associated with carvacrol [38-40] since carvacrol has been shown to inhibit Salmonella growth [41] and Escherichia coli [14] in chickens. Cinnamaldehyde is a constituent of cinnamon and widely applied as flavoring. It has been proven to have strong anti-bacterial activity against Escherichia coli and Salmonella spp. [42]. In vitro, cinnamaldehyde, strongly inhibited Clostridium perfringens and Bacteroides fragilis [43]. Many diverse activities of carvacrol have been proved such as antimicrobial, antitumor, antimutagenic, antigenotoxic, analgesic, antispasmodic, anti-inflammatory, angiogenic, antiparasitic, antiplatelet, insecticidal, antihepa- totoxic and hepatoprotective activities [40]. Alp et al. [22] Studied the effects of dietary oregano essential oil on live chickens performance where it improved the FCR significantly $(\mathrm{P}<0.05)$ as compared with control chickens and birds fed the oregano oil diet consumed significantly $(\mathrm{P}<0.05)$ less feed compared to controls from 21 to $42 \mathrm{~d}$ of age. Capsicum oleoresin contains anti-bacterial activity; it contains the pungent principles, capsaicin which has effects on the resistance to Salmonella enteritidis infection by altering $\mathrm{pH}$ and histological changes [44].

In the present investigation, the effect of the SC on carcass quality revealed increase in percentage of dressing $\%$, front part $\%$, breast meat $\%$, carcass meat $\%$, gizzard weight $\%$ and intestinal diameter, as well as decrease in abdominal fat \%. Jamroz and Kamel [45] reported that broiler chickens fed with herb extract had higher breast weight compared to control group. Contrary to our findings, another researches showed that supplementation of combination of two herb extracts had no effect on carcass characteristics [23, 46]. Alçiçek et al. [29] recorded that herb extract resulted in improvement of chicken carcass but had no effect on abdominal fat percentage.

Immunomodulators administered simultaneously with vaccines might potentiate their specific immune response. Regarding our findings, the $\mathrm{SC}$ can be efficacious as an oral adjuvant to enhance humoral immunity (immuno-globulin production) in response to vaccination. This means that administration of herbal oils could partially counter attacks immune dysfunction. The immune protective effect of herbal essential oils might be due to their antioxidant activity [32, 33] and/or their antimicrobial activities $[37,40]$.

The histological study showed that the addition of the SC increased the villus height and villus height/ crypt depth ratio in ileum compared with controls. However, the ileal crypt depth was decreased by SC supplementation compared with control (Table- 6 and Plate-1). These results confirmed the suggestion reported by Bravo et al. [47], who suggested that the effect of a mixture of carvacrol, cinnamaldehyde, and Capsicum oleoresin might be mediated by a direct increase in dietary energy digestibility or absorption, 
Table-6: Effects of the SC on the ileum morphological parameters of broiler chickens.

\begin{tabular}{lcc}
\hline Parameters & Treated group & Control group \\
\hline Villus length $(\mu \mathrm{m})$ & $195.18 \pm 1.29$ & $155.49 \pm 6.97$ \\
Crypt depth $(\mu \mathrm{m})$ & $22.46 \pm 3.070$ & $45.94 \pm 4.62$ \\
Villus height/crypt depth ratio & 8.70 & 3.38 \\
Minimum villous length & 197.07 & 130.17 \\
Maximum villous length & 200.23 & 169.28 \\
\hline
\end{tabular}
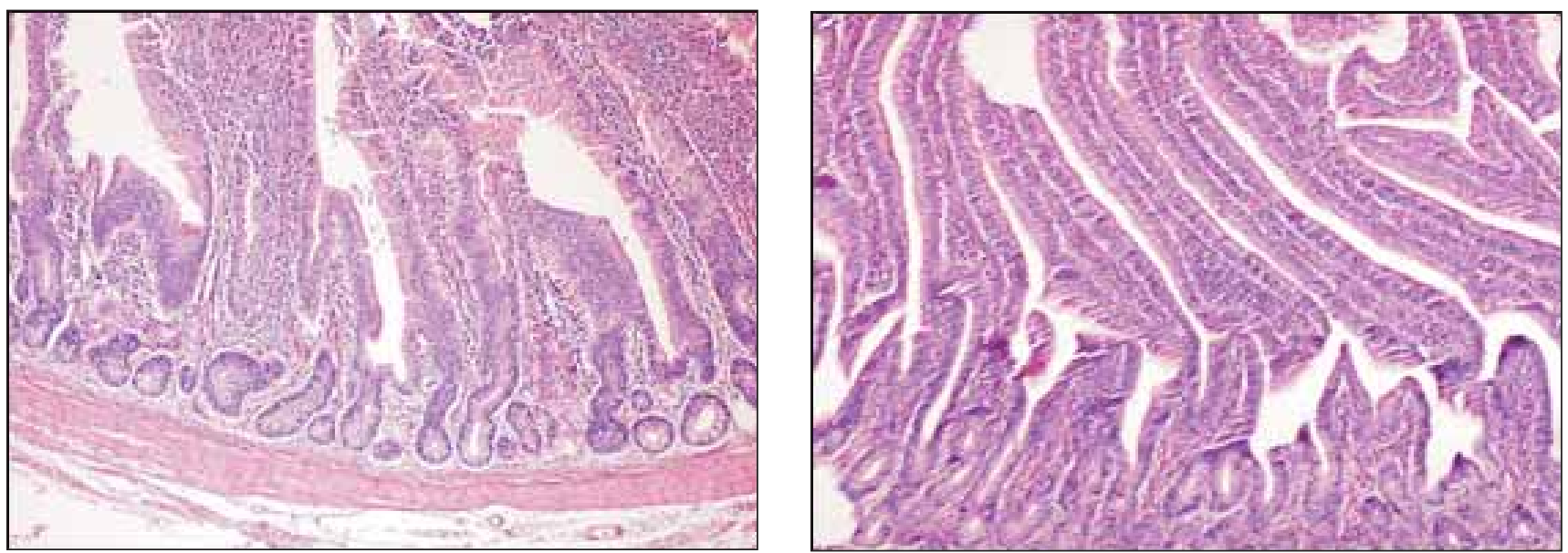

Plate-1. Microscopically examined sections of ileum from blank control chickens revealed no histopathological changes (left fig.). However, ileum of treated chickens with the SC showed very long and folded intestinal villi (right fig.) (HE - X 200).

by a decrease in the energy required for the maintenance of the digestive tract, or a combination of both.

From the data of Table-2, it could be concluded that the SC used in the specified dose degraded the body weight, body weight gain and FCR of the birds at the beginning of the growing period $\left(1^{\text {st }}\right.$ week of age $)$ but then, growth rate and feed efficiency were accelerated and therefore improved with SC. This could be hypothetically attributed to optimizing the intestinal growth and immune system during this period. Then the birds not only profit from this early gut development but also might reduce their maintenance requirements.

\section{Conclusion}

Aforementioned results revealed that administration of a SC to broiler chickens improved zootechnical productivity, mortality, had invaluable positive effect on carcass quality and had a potent immunomodulatory effect (potentiated immune response) that enhanced their vaccination effectiveness. These effects could be related to the improvement of intestinal tract integrity (diameter and villi length) that allows larger surface available for nutrient absorption. Eventually, the SC can be used as a replacement to controversial feed additives. These essential oils might gain much attention for their potential as alternatives to AGP.

\section{Authors' contributions}

MHHA planed the investigation and applied the immune status assessment. ME carried out the productive performance and carcass characteristics together with the statistical analysis of the obtained results. KAA adopted the histomorphological study. All authors participated in draft and revision of the manuscript. All authors read and approved the final manuscript.

\section{Acknowledgments}

The authors acknowledge Pancosma Co, GenevaSwitzerland for supplying of the material of the specific combination of Carvacrol, Cinnamaldehyde, and Capsicum oleoresin (XTRACT ${ }^{\mathrm{TM}}$ 6930). They also acknowledge Animal Production Department, Faculty of Agriculture, Cairo University, Egypt, for carrying out the experimental work. Any person of Panacosma Co. was not involved in the research and publication at any stage either directly or indirectly.

\section{Competing interests}

The authors declare that they have no competing interests.

\section{References}

1. Lee, S.H., Lillehoj, H.S., Jang, S., Kim, D.K., Ionescu, C. and Bravo, D. (2010) Effect of dietary curcuma, capsicum, and lentinus on enhancing local immunity against Eimeria acervulina infection. J. Poult. Sci., 47:89-95.

2. Lillehoj, H.S., Kim, D.K., Bravo, D.M. and Lee, S.H. (2010). Effects of dietary plant-derived phytonutrients on the genome-wide profiles and coccidiosis resistance in the broiler chickens. International Symposium on Animal Genomics for Animal Health. Paris, France. 31 May-2 June 2010.

3. Schuff, S. (2001) Journal says antibiotic use needs restricting. Feedstuffs, 73(44): 5.

4. Karimi, A., Yan, F., Coto, C., Park, J.H., Min, Y., Lu, C., Gidden, J.A., Lay Jr, J.O. and Waldroup, P.W. (2010) Effects of level and source of oregano leaf in starter diets for broiler chicks. J. Appl. Poult. Res., 19:137-145.

5. Yanhong, L. (2011) Effects of plant extracts on immune function and disease resistance in pigs. Doctor of Philosophy in Animal Sciences in the Graduate College of the University of Illinois at Urbana-Champaign, 2011.

6. Engster, H. M., Marvil, D. and Stewart-Brown, B. (2002) 
The effect of withdrawing growth-promoting antibiotics from broiler chickens: A long-term commercial industry study. Poultry Science Association, Inc. 2002.

7. Norton, R. A. (2000) Learning from Europe's troubling example. Watt Poultry USA May 2000.

8. Tokic, V., Lazarevic, M., Sinovic, Z. and Tokic, A. (2007) The influence of different feed additives to performance and immune response in broiler chicken. Acta Veterinaria (Beograd), 57: 217-229.

9. Yang, Y., Iji, P.A., Kocher, A., Mikkelsen, L.L. and Chotc, M. (2007) Effects of mannan oligosaccharide on growth performance, the development of gut microflora, and gut function of broiler chickens raised on new litter. J. Appl. Poult. Res., 16:280-288.

10. Awaad, M., Atta, A., Abd El-Ghany, W. A., Elmenawey, M.A., Ahmed, K., Hassan, A., Nada, A. and Abdelaleem, G. (2011a) Effect of a specific combination of mannanoligosaccharides and $\beta$-glucans extracted from yeast cell wall on the health status and growth performance of ochratoxicated broiler chickens. J. Am. Sci., 7: 82-96.

11. Awaad, M., Atta, A., Elmenawey, M.A., Shalaby, B., Abdelaleem, G., Madian, K., Ahmed, K., Marzin, D., Benzoni, G. and Iskander, D. (2011b) Effect of acidifiers on gastrointestinal tract integrity, zootechnical performance, and colonization of clostridium perfringens and aerobic bacteria in broiler chickens. J. Am. Sci., 7:618-628.

12. Mikulski, D., Zdunczyk, Z., Jankowski, J. and Juskiewicz, J. (2008) Effects of organic acids or natural plant extracts added to diets for turkeys on growth performance, gastrointestinal tract metabolism and carcass characteristics. J. Anim. Feed Sci., 17:233-246.

13. Windisch, W., Schedle, C. and Kroismaryr, A. (2008) Use of phytogenic products as feed additives for swine and poultry. J. Anim. Sci., 86 40-148.

14. Renata S., Lauková, A., Chrastinová, L., Strompfová, V., Simonová, M. P., Plachá, I., Vasilková, Z., Chrenková, M. and Faix, S. (2012) Beneficial effect of plant extracts in rabbit husbandry. Acta Vet. Brno., 81:245-250.

15. Sarac, N., Ugur, A., Duru, M.E. and Varol, O. (2009). Antimicrobial activity, antioxidant activity, and chemical composition of Origanum onites L. and Origanum vulgare L. ssp. hirtum (Link) ietswaart from Mugla (Turkey). Acta Horticul, 826: 397-404.

16. Kollanoor-Johny, A., Upadhyay, A., Baskaran, S. A., Upadhyaya, I., Mooyottu, S., Mishra, N., Darre, M.J., Khan, M.I., Donoghue, A.M., Donoghue, D. J. and Venkitanarayanan, K. (2012) Effect of therapeutic supplementation of the plant compounds trans-cinnamaldehyde and eugenol on Salmonella enterica serovar enteritidis colonization in market-age broiler. J. Appl. Poult. Res., 21: 816-822.

17. Lee, S.H., Lillehoj, H.S., Jang, S., Lillehoj, E., Min, W. and Bravo, D. (2013) Dietary supplementation of young broiler chickens with Capsicum and turmeric oleoresins increases resistance to necrotic enteritis. Brit. J. Nutr., 9: 1-8.

18. Sökmen, M., Serkedjieva, J., Daferera, D., Gulluce, M., Polissiou, M., Tepe, B., Akpulat, H. A., Sahin, F., and Sokmen, A. (2004) In vitro antioxidant, antimicrobial, and antiviral activities of the essential oil and various extracts from herbal parts and callus cultures of Origanum acutidens. J. Agric. Food Chem., 52:3309-3312.

19. Dundar, E., Olgun, E., Isiksoy, S., Kurkcuoglu, M., Baser, K.H. and Bal, C. (2008) The effects of intra-rectal and intraperitoneal application of Origanum onites L. essential oil on 2, 4, 6-trinitrobenzenesulfolic acid-induced colitis in the rat. Exp. Toxicol. Pathol., 59:399-408.

20. Lee, J., Chang, K. and Kim, G. (2009) Composition and antiinflammatory activities of Zanthoxylum schinifolium essential oil: suppression of inducible nitric oxide synthesis, cyclooxygenase-2, cytokines, and cellular adhesion. J. Sci. Food Agric., 89:1762-1769.

21. Lee, K.W., Everts, H. and Beynen, A.C. (2004) Essential oils in broiler nutrition. Int. J. Poult. Sci., 3:738-752.
22. Alp M., Midilli, M., Kocabağl, N., Yılmaz, H., Turan, N., Garg1l, A. and Acar, N. (2012) The effects of dietary oregano essential oil on live performance, carcass yield, serum immunoglobulin $\mathrm{G}$ level, and oocyst count in broilers. $J$. Appl. Poult. Res., 21:630-636.

23. Hernandez, F., Madrid, J., Garcia, V., Orengo, J. and Megias, M.D. (2004) Influence of two plants extracts on broiler performance, digestibility, and digestive organ size. Poult. Sci., 83:169-174.

24. Timmerman, H., Veldman, A., van den Elsen, E., Rombouts, F. and Beynen, A. (2006) Mortality and growth performance of broilers given drinking water supplemented with chickenspecific probiotics. Poult. Sci., 85:1383-1388.

25. Swayne, D.E., Glisson, J.R., Jackwood, M.W., Pearson, J.E. and Reed, W.M. (1998) A laboratory manual for the isolation and identification of avian pathogens. $4^{\text {th }} \mathrm{Ed}$, American Association of Avian Pathologist Inc., Kennett Square, Pennsylvania, USA. p156-163.

26. Bancroft, J.D., Stevens, A. and Turner, D.R. (1996) Theory and Practice of Histological Techniques. $4^{\text {th }}$ Ed. New York, Churchill Livingstone. p99-112.

27. SAS, Institute. (2004) SAS User's Guide, Statistics, Version 6.12 edition. SAS Institute Inc., Cary, NC.USA. p170.

28. Bassett, R., (2000) Oreganos positive impact on poultry production. Wr Poult.-Elsevier, 16:31-34.

29. Alçiçek, A., Bozkurt, M. and Çabuk, M. (2003) The effects of an essential oil combination derived from selected herbs growing wild in turkey on broiler performance. S. Afr. J. Anim. Sci., 33:89-94.

30. Cross, D. E., Acamovic, T., Deans, S. G. and Mcdevitt, R. M. (2002) The effect of dietary inclusions of herbs and their volatile oils on the performance of growing chickens. $\mathrm{Br}$. Poult. Sci. 43:33-35.

31. Bolukbasi, S. C., Erhan, M.K. and Ozkan, A. (2006) Effect of dietary thyme oil and vitamin $\mathrm{E}$ on growth, lipid oxidation, meat fatty acid composition and serum lipoproteins of broilers. S. Afr. J. Anim. Sci., 36:189-196.

32. Botsoglou, N., Florou-Paner, P., Christaki, E., Fletouris, D.G. and Spais, A.B. (2002) Effect of dietary oregano essential oil on performance of chickens and on iron induced lipid oxidation of breast, thigh and abdominal fat tissues. Br. Poult. Sci., 43:223-230.

33. Botsoglou, N., Christaki, E., Paner, P.F., Giannenas, I., Papageorgiou, G. and Spais, A. (2004) The effect of a mixture of herbal essential oils or a-tocopheryl acetate on performance parameters and oxidation of body lipid in broiler. S. Afr. J. Anim. Sci., 34:52-61.

34. Gill, C. (2001) Safe and sustainable feed ingredients. Feed Int., 22: 40-45.

35. Azaz, D., Demirci, F., Satil, F., Kürkcüog, U. and Baser, K.H. (2002) Antimicrobial activity of some Satureja oils. Z. Naturforsch., 57:817-821.

36. Dorman, H. J. D. and Deans, S. G. (2000) Antimicrobial agent from plants: antimicrobial activity of plant volatile oils. J. Appl. Microbiol. 88:308-316.

37. Deans, S.G., and Ritchie, G. (1987) Antibacterial properties of plant essential oils. Int. J. Food Microbiol. 5:165-180.

38. Burt, S.A., Vlielander, R., Haagsman, H.P. and Veldhuizen, E.J. (2005) Increase in activity of essential oil components carvacrol and thymol against Escherichia coli $\mathrm{O} 157: \mathrm{H} 7$ by addition of food stabilizers. J. Food Prot., 68:919-926.

39. Veldhuizen, E., Tjeerdsma, J., Zweijtzer, C., Burt, S. and Haagsman, H. (2006) Structural requirements for the antimicrobial activity of carvacrol. J Agric Food Chem., 54:1874-879

40. Baser, K.H. (2008) Biological and pharmacological activities of carvacrol and carvacrol bearing essential oils. Curr Pharm Des., 14: 106-119.

41. Burt, S.A., Fledderman, M., Haagsman, H.P., van Knapen, F. and Veldhuizen, E.J. (2007) Inhibition of Salmonella enterica serotype Enteritidis on agar and raw chicken by carvacrol vapors. Int. J. Food Microbiol, 119:346-350. 
42. Chang, S.T., Chen, P.F. and Chang, S.C. (2001) Antibacterial activity of leaf essential oils and their constituents from Cinnamomum osmophloeum. J. Ethnopharmacol, 77:123-127.

43. Lee, H.S., and Ahn, Y.J. (1998) Growth inhibiting effects of cinnamomum cassia bark-derived materials on human intestinal bacteria. J. Agri. Food Chem., 46:8-12.

44. McElroy, A.P., Manning, J.G., Jaeger, L.A., Taub, M., Williams, J.D. and Hargis, B.M. (19940. Effect of prolonged administration of dietary capsaicin on broiler growth and Salmonella enteritidis susceptibility. Avian Dis., 38:329333.

45. Jamroz, D. and Kamel, C. (2002) Plant extracts on immunity, health, and performance. J. Anim. Sci., 80:41.

46. Sarica, S., Ciftci, A., Demir, E., Kilinc, K. and Yildirim, Y. (2005) Use of antibiotic growth promoter and two herbal natural feed additives with and without exogenous enzymes in wheat based broiler diets. S. Afr. Anim. Sci., 35:61-72.

47. Bravo, D., Utterback, P. and Parsons, C.M. (2011) Evaluation of a mixture of carvacrol, cinnamaldehyde, and capsicum oleoresin for improving growth performance and metabolizable energy in broiler chicks fed corn and soybean meal. J. Appl. Poult. Res. 20:115-120.

48. Bell, D.D. and Weaver, Jr.W.D. (2002) Commercial Chicken Meat and Egg Production. $5^{\text {th }}$ Ed. Kluwer academic Publishers. USA. p1109-1128.

$* * * * * * * *$ 